\title{
PENGGUNAAN DESAIN PEMBELAJARAN DALAM MENINGKATKAN KETERAMPILAN MEMBACA SISWA SD KELAS III SDN CURUG 1
}

\author{
Ina Magdalena ${ }^{1}$, Tio Saputra ${ }^{2}$, Sihury Wellya Pamungkas ${ }^{3}$, Raihan Fadhlurahman Jamirullah ${ }^{4}$ \\ Universitas Muhammadiyah Tangerang \\ inapgsd@gmail.com , tiosaputra169@gmail.com
}

\begin{abstract}
This research was conducted at SDN Curug 1. The purpose of this study was to determine the use of learning designs in improving reading skills of third grade students. The object of this research is a class III teacher at SDN Curug 1. The method used in this research is qualitative research using observation, interview and documentation techniques. Class teachers at SDN Curug 1 use the design method of learning to read aloud and fast and the teacher also uses the existing library in the form of interesting reading books so that students are expected to be able to improve their reading skills.
\end{abstract}

Keywords : Learning Design, Reading Skills, Qualitative Research

\begin{abstract}
Abstrak : Penelitian ini dilakukan di SDN Curug 1 tujuan dilakukannya penelitian ini adalah untuk mengetahui penggunaan Desain Pembelajaran dalam meningkatkan keterampilan membaca siswa kelas III. Objek penelitian ini adalah seorang guru kelas III di SDN Curug 1 metode yang digunakan dalam penelitian ini adalah penelitian kualitatif dengan menggunakan teknik observasi, wawancara dan dokumentasi. guru kelas di SDN Curug 1 menggunakan metode Desain pembelajaran membaca nyaring dan cepat dan guru juga memanfaatkan perpustakaan yang ada berupa buku - buku bacaan yang menarik sehingga siswa diharapkan mampu meningkatkan keterampilan membacanya.
\end{abstract}

Kata Kunci : Desain Pembelajaran, Keterampilan Membaca, Penelitian Kualitatif

\section{PENDAHULUAN}

Desain pembeljaran adalah proses untuk menentukan metode pembelajaran apa yang paling baik untuk dilaksanakan, agar timbul perubahan pengetahuan dan keterampilan pada diri siswa ke arah yang dikehendakinya. Yang akan dilakukan oleh seorang guru di dalam kelas, desain pembelajaran meliputi tujuan pembelajaran yang akan dicapai, pengembangan materi pengajaran atau desain mata pelajaran. Desain 
pembelajaran berkenaan dengan pemahaman, peningkatan dan penerapan metodemetode pembelajaran (Setyosari, 2020)

Setiap orang yang berpengalaman menjadi praktis profesional dalam kegiatan instruksional seperti para pengajar diberbagai jenjang dan jenis pendidikan, tentu memiliki kepercayaan tentang bagaimana peserta didik belajar. Kepercayaan itu dapat bersumber dari pengalaman pribadi, refleksi diri, diskusi dengan teman sejahwat dan membaca hasil penelitian sendiri dan orang lain. Dari kepercayaan itu terdapat beberapa prinsip yang digunakan oleh pendesain instruksional. Desain pembelajaran dapat didefinisikan sebagai suatu proses sistematik dan reflektif untuk menjabarkan prinsip-prinsip belajar dan pembelajaran kedalam perencanaan untuk keperluan perencanaan pembelajaran, aktifitas aktifitas pembelajanran dan evaluasi.

Berikut ini prinsip prinsip yang digunakan. dalam pengembangan instruksional menurut Filbeck dapat dikelompokkan menjadi dua belas macam yaitu :

1. Prinsip pertama. Respons-respons baru (new responses) diulang sebagai akibat dari respons tersebut. Bila respons itu berakibat menyenangkan, peserta didik cenderung untuk mengulang respons tersebut karena ingin memelihara akibat yang menyenangkan. Bila akibat respons itu kurang menyenangkan, peserta didik cenderung mencari jalan yang dapat mengurangi rasa tidak menyenangkan, peserta didik cenderung mencari jalan yang dapat mengurangi rasa tidak menyenangkan tersebut dengan cara menghindari respons yang sama atau melakukan perilaku lain. Salah satu impikasinya dalam kegiatan instruksional adalah perlunya pemberian umpan balik positif atau pujian dengan segera atas keberhasilan atau respons yang benar dari peserta didik.

2. Prinsip kedua. Perilaku tidak hanya dikontrol oleh akibat dari respons, tetapi juga di bawah pengaruh kondisi atau tanda-tanda yang terdapat dalam lingkungan peserta didik. Kondisi atau tanda-tanda tersebut berbentuk tulisan, gambar, komunikasi verbal, keteladan guru, atau perilaku sesama peserta didik. Implikasinya prinsip kedua ini pada teknologi instruksional adalah perlunya menyatakan tujuan instruksional secara jelas kepada peserta didik sebelum pelajaran dimulai agar peserta 
didik bersedia belajar lebih giat. Tujuan instruksional itu berisi pengetahuan, keterampilan atau setiap perilaku yang akan dapat dilakukan peserta didik setelah menyelesaikan pelajaran. Implikasi lainnya adalah penggunaan berbagai metode dan media agar dapat mendorong keaktifan peserta didik dalam proses belajarnya.

3. Prinsip ketiga. Perilaku yang ditimbulkan oleh tanda-tanda tertentu akan hilang atau berkurang frekuensinya bila tidak diperkuat dengan pemberian akibat yang menyenangkan. Karena itu pengetahuan dan keterampilan baru yang telah dikuasai harus sering dimunculkan dan diberi akibat yang menyenangkan agar keterampilan baru itu selalu digunakan. Implikasinya adalah pemberian isi pelajaran yang berguna pada peserta didik dalam dunia kehidupan serta pemberian umpan balik berupa imbalan dan penghargaan terhadap keberhasilan peserta didik.

4. Prinsip ketiga. Perilaku yang ditimbulkan oleh tanda-tanda tertentu akan hilang atau berkurang frekuensinya bila tidak diperkuat dengan pemberian akibat yang menyenangkan. Karena itu pengetahuan dan keterampilan baru yang telah dikuasai harus sering dimunculkan dan diberi akibat yang menyenangkan agar keterampilan baru itu selalu digunakan. Implikasinya adalah pemberian isi pelajaran yang berguna pada peserta didik dalam dunia kehidupan serta pemberian umpan balik berupa imbalan dan penghargaan terhadap keberhasilan peserta didik.

5. Prinsip kelima. Belajar menggeneralisasikan dan membedakan adalah dasar untuk belajar sesuatu yang kompleks seperti pemecahan masalah. Uraian materi pelajaran perlu diperjelas dengan contoh yang positif dan negatif. Untuk menjelaskan bilangan genap, misalnya, guru perlu memberikan contoh bilangan genap dan contoh bilangan ganjil.

6. Prinsip keenam. Status mental peserta didik untuk menghadapi pelajaran akan memengaruhi perhatian dan ketekunannya selama proses belajar. Implikasinya adalah pentingnya menarik perhatian peserta didik agar dapat mempelajari isi pelajaran dengan baik 
7. Prinsip ketujuh. Kegiatan belajar yang dibagi menjadi langkah-langkah kecil dan disertai umpan balik untuk menyelesaikan setiap langkah akan membantu sebagian besar peserta didik. Implikasinya penggunaan buku teks terprogram

8. Prinsip kedelapan. Kebutuhan memcah materi belajar yang kompleks menjadi kegiatan-kegiatan kecil akan dapat dikurangi bila materi belajar dapat diwujudkan dalam satu model. Implikasinya berupa penggunaan media dan metode instruksional yang dapat menggambarkan materi yang kompleks kepada peserta didik seperti: model, realia (benda sebenarnya), film, program televisi, program video, drama, dan demonstrasi.

9. Prinsip kesembilan. Keterampilan tingkat tinggi seperti keterampilan memecahkan masalah adalah perilaku kompleks yang terbentuk dari komposisi keterampilan dasar yang lebih sederhana. Implikasinya yaitu tujuan instruksional umum harus dirumuskan dalam bentuk hasil belajar yang operasional agar dapat dianalisis menjadi tujuan-tujuan yang lebih khusus.

10. Prinsip kesepuluh. Belajar cenderung cepat dan efisien serta menyenangkan bila peserta didik diberi informasi bahwa ia menjadi lebih mampu dalam keterampilan memecahkan masalah. Ia cenderung belajar lebih cepat bila diberi informasi tentang kualitas penampilannya dan bagaimana cara meningkatkannya lebih baik.

11. Prinsip kesebelas. Perkembangan dan kecepatan belajar peserta didik bervariasi, ada yang maju dengan cepat, ada yang lebih lambat. Di samping itu, perkembangan dan kecepatan belajar seorang peserta didik tidak stabil dari suatu hari ke hari yang lain dan tidak sama dari satu mata pelajaran ke mata pelajaran yang lain.

12. Prinsip kedua belas. Dengan persiapan, peserta didik dapat mengembangkan kemampuan mengorganisasikan kegiatan belajarnya sendiri dan menimbulkan umpan balik bagi dirinya untuk membuat respons yang benar. Pemberian kemungkinan bagi peserta didik untuk 
memilih waktu, cara, dan sumber-sumber lain, di samping yang telah ditetapkan dalam sistem instruksional agar dapat membuat dirinya mencapai tujuan instruksional.

Dari kedua belas prinsip tersebut dapat disimpulkan bahwa desain instruksional adalah hal yang kompleks tetapi juga perlu untuk diterapkan agar tercapainya pembelajaran yang efektif dan juga efisien.

Untuk menghadapi era globalisasi ini semua masalah dan informasi dapat dengan cepat diketahui oleh seluruh dunia melalui berbagai media yang ada, termasuk informasi tentang perkembangan ilmu pengetahuan dan teknologi. Salah satu kegiatan yang digunakan sebagai penyebaran informasi dalam belajar yaitu membaca menjadi salah satu kegiatan yang sangat penting. Informasi yang didapat hanya dari melihat dan mendengar, dimungkinkan akan cepat terlupakandan hilang, tetapi jika didapat dari media cetak, informasi tersebut akan tersimpandalam waktu yang relatif lama dan bisa dicari kembali jika diperlukan dalamkegiatan membaca. Pada era globalisasi ini, dimana kemajuan teknologi sudah berkembang pesat, minat baca pada generasi baru cenderung menurun dan tidak lebih baik dari generasi sebelumnya. Penyebabnya antara lain semakin canggihnya piranti audio visual yang menyebabkan generasi baru lebih senang memanjakan mata dan telinganya dari pada menumbuhkan semangat dan kebiasaan membaca serta ketiadaan mata pelajaran membaca yang seharusnya diajarkan sejak dini pada pendidikan dasar (Ginting, 2013) Keberhasilan belajar siswa dalam mengikuti proses kegiatan belajar mengajar di sekolah sangat di tentukan oleh penguasaan kemampuan membaca (Susanna Vonny Noviana Rante , 2014). Siswa yang tidak mampu membaca dengan baik akan mengalami kesulitan dalam mengikuti kegiatan pembelajaran untuk semua mata pelajaran. Siswa akan mengalami kesulitan dalam menangkap dan memahami informasi yang disajikan dalam berbagai buku pelajaran, buku-buku bacaan penunjang dan sumber-sumber belajar tertulis yang lain. Siswa tersebut akan lamban sekali dalam menyerap pelajaran. Akibatnya, kemajuan belajarnya juga lamban jika dibandingkan dengan siswa yang tidak mengalami kesulitan dalam membaca. 
Di era pendidikan sekarang keterampilan membaca di sekolah dasar masih sangat rendah. Membaca merupakan suatu kesatuan kegiatan yang terpadu yang mencakup beberapa kegiatan seperti mengenali huruf dan kata-kata menghubungkannya dengan bunyi dan maknanya, serta menarik kesimpulan menganai maksud bacaan membaca merupakan satu alat pembelajaran yang efektif karena memberi kekuatan pada seorang murid untuk membuat keputusan yang tepat dalam meningkatkan proses pembelajaran dan pemikiran. Seorang pembaca dapat memahami dan menilai teks yang dibaca dengan mengaktifkan skema prosedur dan isi skema yang terdapat dalam dirinya. Proses membaca merupakan proses kognitif yang di alami secara individu. Proses kognitif ini sangat penting untuk membantu meningkatkan daya baca ( Nambiar 2005; Urquhart \& weir1998).

Membaca adalah proses yang dilakukan serta digunakan oleh pembaca untuk memperoleh pesan, yang hendak disampaikan oleh penulis melalui bahasa tulis. Membaca pada dasarnya merupakan awal dari penguasaan ilmu. Semua ilmu yang ada di bumi ini tidak akan pernah bisa dipelajari jika tidak didahului dengan kemampuan untuk membaca. Dengan membaca diharapkan mata rantai dalam penguasaan sebuah ilmu tidak akan hilang. Mata rantai itu adalah mendengar, membaca dan melihat. Sebagai salah satu mata rantai dalam penguasaan ilmu, membaca untuk dijadikan sebagai kebiasaan atau bahkan budaya dalam kehidupan sehari-hari masih sulit dilakukan. Hal ini mungkin berasal dari budaya Indonesia yang berlatar budaya tutur (oral culture), dimana legenda, dongeng, hikayat dan cerita-cerita rakyat yang berkembang sejak lama di Indonesia dan merupakan media pembelajaran yang paling mudah untuk dilaksanakan karena bisa dipelajari dari pada membaca sebuah buku untuk merubah pengetahuan relatif lebih lama padahal kebiasaan dan budaya membaca itu identik dengan budaya belajar yang justru amat penting bagi kemajuan bangsa Indonesia di masa mendatang.

kegiatan membaca ini sangat ditentukan oleh kegiatan fisik dan mental yang menuntut seseorang untuk menginterpresikan simbol-simbol tulisan dengan aktif dan kritis sebagai pola komunikasi dengan diri sendiri, agar pembaca dapat menemukan makna tulisan dan memperoleh informasi yang dibutuhkan. (Erma Yulia Saputri, Riris Setyo Sundari, \& Zainal Arifin, 2019). 
Keterampilan membaca sangat penting dalam kehidupan, karena setiap aspek kehidupan tidak luput dari kegiatan membaca. Oleh karena itu keterampilan membaca harus segera dikuasai oleh para siswa di SD karena keterampilan ini secara langsung berkaitan dengan seluruh proses belajar siswa di SD. Siswa yang tidak mampu membaca dengan baik akan mengalami kesulitan dalam mengikuti kegiatan pembelajaran untuk semua mata pelajaran. Siswa akan mengalami kesulitan dalam menangkap dan memahami informasi yang disajikan dalam berbagai buku pelajaran, buku-buku bahan penunjang dan sumber-sumber belajar lainnya, akibat kesulitan membaca tersebut kemajuan belajarnya juga lamban jika dibandingkan dengan teman-temannya yang tidak mengalami kesulitan dalam membaca.

Menurut (Dalman, 2017, hal. 12), dilihat dari tujuan seseorang dalam membaca, terdapat banyak tujuan membaca. Dalam hal ini, tujuan tersebut bergantung pada kepentingan dan bahan bacaan yang dihadapi setiap orang. Menurut (Nurhadi, 2010, hal. 136), pada hakikatnya tujuan membaca adalah modal utama membaca. Tujuan yang jelas akan memberikan motivasi intrinsik yang besar bagi seseorang. Seseorang yang sadar sepenuhnya akan tujuan membacanya akan dapat mengarahkan sasaran daya pikir kritisnya dalam mengolah bahan bacaan sehingga memperoleh kepuasan dalam membaca.

Pembelajaran membaca di SD diselenggarakan dalam rangka pengembangan kemampuan membaca yang mutlak harus dimiliki oleh setiap warga negara agar dapat mengembangkan diri secara berkelanjutan. Melalui pembelajaran di SD, siswa diharapkan memperoleh dasar - dasar kemampuan membaca disamping kemampuan menulis dan menghitung, serta kemampuan esensial lainnya. Dengan dasar kemampuan itu, siswa dapat menyerap berbagai pengetahuan yang sebagian besar disampaikan melalui tulisan.

Keterampilan membaca bisa diperoleh dimana saja, keterampilan membaca pada umumnya diperoleh dengan cara mempelajarinya di sekolah. Keterampilan berbahasa ini merupakan suatu keterampilan yang sangat unik serta berperan penting bagi pengembangan pengetahuan, dan sebagai alat komunikasi bagi kehidupan manusia, dikatakan unik karena tidak semua manusia, walaupun telah memiliki keterampilan membaca, dapat mengembangkannya menjadi alat untuk memberdayakan dirinya 
atau bahkan menjadikannya budaya bagi dirinya sendiri, dikatakan penting bagi pengembangan pengetahuan karena persentase transfer ilmu pengetahuan terbanyak dilakukan melalui membaca (Iskandarwasid, 2011).

Permasalahan rendahnya keterampilan membaca yang ada pada siswa kelas 3 SDN Curug 1 harus segera diatasi, tidak bisa dibiarkan begitu saja, karena dapat menimbulkan dampak yang sangat besar dan dapat merugikan bagi siswa, guru dan juga sekolah sebagai penyelenggara pendidikan di daerah tersebut. Dampak-dampak tersebut akan semakin terasa setelah mereka menduduki kelas kelas yang lebih tinggi, oleh sebab itu siswa yang keterampilan membacanya rendah akan menghadapi suatu kendala ataupun tantangan yang besar, mengingat bahwa pada kelas tersebut siswa harus menerima materi pelajaran lebih kompleks, karena hampir semua mata pelajaran membutuhkan keterampilan membaca.

Faktor yang berperan terhadap kemampuan membaca adalah faktor fisiologi, faktor intelektual, faktor lingkungan dan faktor psikologis. Menurut (Ratna \& Wulan, 2010, hal. 169), faktor-faktor yang mempengaruhi kemampuan membaca adalah faktor internal:

a) Fisiologis: mata dan telinga

b) Psikologis: inteligensi, kemampuan persepsi visual, penguasaan kosakata, sikap terhadap membaca, dan minat membaca

Serta faktor eksternal yang mempengaruhi kemampuan membaca:

a) Pengajaran: metode mengajar dan program yang menarik, kurikulum, dan fasilitas yang tersedia

b) Sosial: motivasi dari lingkungan.

Salah satu solusi yang bisa di gunakan di sekolah dasar untuk meningkatkan keterampilan membaca adalah dengan membuat rancangan atau desain pembelajaran, menggunakan model-model desain pembalajaran dan membuat strategi desain pembelajaran yang tepat agar tujuan pembelajaran yang telah dirancang berjalan dengan baik. Model merupakan suatu konsep untuk, mengajar suatu materi dalam mencapai tujuan tertentu dalam model mencakup strategi pendekatan, metodde maupun teknik. Model pembelajaran merupakan kerangka konseptual yang berupa 
pola prosedur sistematik yang dikembangkan berdasarkan teori dan digunakan dalam mengorganisasikan proses belajar mengajar terjadi interaksi dua arah antara pengajar dan peserta didik.

Sebelum proses pembelajaran berlangsung model pembelajaran harus sudah disediakan oleh guru. Model pembelajaran yang digunakan haruslah sesuai dengan materi dan karakteristik siswa, agar tujuan pembelajaran dapat tercapai dengan baik. Untuk dapat menyampaikan pelajaran dengan baik agar siswa lebih mudah memahami pelajaran seorang guru selain harus menguasai materi juga dituntut untuk dapat terampil dalam memilih dan menggunakan model mengajar yang tepat sesuai dengan situasi dan kondisi yang dihadapi.

Untuk meningkatkan keterampilan membaca pada siswa kelas 3 SDN Curuug 1 guru haruslah bisa membuat rancangan desain pembelajaran atau model pemebelajaran dan guru juga selain harus menguasai materi juga harus bisa mengenali karakteistik siswa kelas 3 tersebut. Agar guru dapat menyiapkan bahan bacaan dan materi pelajaran yang baik sehingga siswa merasa senang dan gembira dan tujuan pembelajaran untuk meningkatkan keterampilan membaca siswa kelas 3 di SDN Curug 1 bisa tercapai dengan baik.

\section{METODE PENELITIAN}

Metode yang digunakan pada penilitian ini adalah menggunakan metode penelitian kualitatif. Metode penelitian kualitatif merupakan metode penelitian yang lebih menekankan pada aspek pemahaman secara mendalam terhadap suatu masalah dari pada melihat permasalahan untuk penelitian generealisasi (Setiawan, 2018). Metode penelitian ini lebih suka menggunakan teknik analisis mendalam ( indeph analysis), yaitu mengkaji masalah secara kasus perkasus karena metodologi kualitatif yakin bahwa sifat suatu masalah satu akan berbeda dengan sifat masalah lainnya. Menurut (Moleong, 2007) sumber data penelitian kualitatif adalah tampilan yang berupa katakata lisan atau tertulis yang dicermati oleh peneliti, dan benda-benda yang di amati sampai detailnya agar dapat ditangkap makna yang tersirat dalam dokumen atau bendanya. Penelitian kualitatif berlandaskan pada filsafat postpositivisme, karena 
digunakan untuk meneliti pada kondisi obyek yang alamiah, ( sebagai lawannya eksperimen ), dimana peneliti adalah instrument kunci, pengambilan sampel sumber data dilakukan secara purposive dan snowball, teknik pengumpulan dengan trianggulasi ( gabungan ), analisis data bersifat induktif/kualitatif, dan hasil penelitian kualitatif lebih menekankan makna dari pada generealisasi ( sugiyono , 2011).

Pada penelitian ini proses pelaksanaannya dilakukan dengan observasi,wawancara dan dokumentasi. dalam pengumpulan data penelitian kualitatif observasi lebih dipilih sebagai alat karena peneliti dapat melihat, mendengar atau merasakan informasi yang ada secara langsung.

\section{Tempat dan waktu penelitian}

Penelitian ini dilakukan di SDN curug 1 dan penelitian ini dilaksanakan pada bulan januari 2021

\section{Subyek dan Obyek Penelitian}

Subyek dari penelitian ini adalah Guru Kelas 3 dari sekolah SDN Curug 1

\section{Teknik dan instrumen pengumpulan data}

\section{Teknik Pengumpulan data}

Teknik pengumpulan data dilakukan dengan pendekatan kualitatif yaitu dengan observasi, wawancara dan dokumentasi.

a. Wawancara merupakan sebuah percakapan antara dua orang atau lebih, yang pertanyaan nya diajukan oleh peneliti kepada subyek atau sekelompok subyek penelitian untuk dijawab pada penelitian kualitatif, wawancara mendalam dapat dilakukan dengan dua cara yaitu, wawancara sebagai strategi utama dalam mengumpulkan data dan wawancara sebagai strategi penunjang teknik lain dalam mengumpulkan data.pencatatan data selama wawancara penting sekali karena data yang akan dianalisis didasarkan atas kutipan hasil wawancara. Oleh karena itu, pencatatan data itu perlu dilakukan dengan cara yang sebaik dan setepat mungkin.menurut (J. Moleong, 2014). pencatatan sumber data melalui wawancara atau pengamatan merupakan hasil gabungan dari kegiatan melihat,mendengar, dan bertanya. Hal ini dilakukan agar obyek peneliti yaitu guru dan siswa 
lebih leluasa menjawab pertanyaan secara fakta. Dalam wawancara peneliti mennggunakan via daring. Dalam penelitian ini, wawancara dilakukan kepada guru kelas 3 SDN Curug 1.

b. Obsevasi dalam pengumpulan data penelitian kualitatif, obsrvasi lebih dipilih sebagai alat karena peneliti dapat melihat, mendengar, atau merasakan informasi yang ada secara langsung. Saat peneliti terjun langsung ke lapangan, informasi yang muncul bisa saja sangat berharga sebagai mana yang telah di ungkapkan stake (2010:90) many qualitative researhers prefer observation data information that can be seen directly by the researcher or heard or felt. Oleh karena it, dengan observasi peneliti dapat lebih mudah dalam mengolah informasi yang ada atau bahkan informasi yang muncul secara tiba-tiba tanpa diprediksi terlebih dahulu.

c. Dokumentasi digunakan untuk mengumpulkan data ari sumber insani. Sumber ini terdiri dari dokumen dan rekaman. Studi dokumentasi merupakan pelengkap dari penggunaan metode observasi dan wawancara dalam penelitian kualitatif.

\section{Teknik analisis data}

Tekhnik analisi data yang digunakan dalam penilitian ini menggunakan teknik analisis kualitatif. Miles dan huberman menawarkan pola umum analisis dengan mengikuti model alir. Dalam model alir terssebut peneliti melakukan tiga kegiatan analisis data secara serempak yaitu data reduction (Reduksi data), data display (penyajian data), dan Penarikan kesimpulan/verifikasi

1. Data reduction (reduksi data)

Data yang diperoleh dari penelitian beragam, apalagi dengan memadukan beberapa teknik. Mereduksi data berarti merangkum, memilih hal - hal yang pokok, memfokuskan pada hal - hal yang penting, dicari tema dan polanya dan membuang yang tidak perlu.

2. Data display (penyajian data)

Dalam penelitian kualitatif, penyajian data bisa dilakukan dalam bentuk uraian singkat, bagan, hubungan antar teori dan sebagainya.

3. Conclusion (penarikan kesimpulan) 
Kesimpulan dalam penelitian kualitatif dapat berupa deskripsi atau gambaran suatu obyek yang sebelumnya masih remang - remang sehingga setelah diteliti menjadi jelas.

Berdasarkan pengertian di atas, dalam penelitian ini menggunakan teknik analisis data kualitatif. Terdapat tiga jalur analisis data yaitu data reduction (reduksi data), data display (penyajian data), dan penarikan kesimpulan.

Data reduction, pada tahap ini dilakukan pemilihan tentang relevan tidaknya antara data dengan tujuan penelitian. Data yang diperoleh dari penelitian yang beragam dengan memadukan beberapa teknik. Informasi dari lapangan sebagai bahan mentah yang kemudian diringkas, disusun lebih sistematis, serta ditonjolkan pokok - pokok yang penting sehingga lebih mudah dikendalikan. Setelah tahap mereduksi data selesai dilakukan, kemudian dilanjutkan dengan display data untuk dapat melihat gambaran keseluruhan atau bagian Bagian tertentu dari gambar keseluruhan. Pada tahap ini peneliti berupaya mengklasifikasikan dan menyajikan data sesuai dengan pokok permasalahan yang diawali dengan pengkodean pada setiap sub pokok permasalahan. Untuk memudahkan memperoleh kesimpulan dari lapangan, maka penyajian data bisa dilakukan dalam bentuk uraian singkat, bagan, serta hubungan antar teori.

Tahap ketiga dalam teknik analisis data menurut Miles and Huberman adalah penarikan kesimpulan/verifikasi Kegiatan yang dimaksudkan untuk mencari makna data yang dikumpulkan dengan mencari hubungan, persamaan atau perbedaan. Penarikan kesimpulan dilakukan dengan jalan membandingkan kesesuaian pernyataan dari subyek penelitian dengan makna yang terkadnung dengan konsep - konsep dasar dalam penelitian tersebut. Kesimpulan dalam penelitian kualitatif dapat berupa deskripsi atau gambaran suatu objek yang sehingga setelah diteliti menjadi jelas.

\section{HASIL PENELITIAN DAN PEMBAHASAN}

Penelitian ini di lakukan di SDN curug 1, setelah peneliti mendapatkan ijin dari kepala sekolah untuk melakukan observasi dan wawancara kepada guru kelas 3 di 
SDN Curug 1. Barulah peneliti menyiapkan penyusunan konsep pelaksanaan, membuat jadwal wawancara dengan guru kelas dan menyiapkan beberapa pertanyaan yang akan ditanyakan kepada narasumber.

Setelah peneliti melakukan persiapan barulah peneliti melakukan wawancara dengan memberikan beberapa pertanyaan, seperti:

1. sejauh mana kemampuan siswa dalam mengikuti pembelajaran kerampilan membaca?

2. Bagaimana kondisi suasana kelas ketika siswa mengikuti pembelajaran keterampilan membaca?

3. Bagaimana pemilihan strategi atau metode Desain Pembelajaran yang digunakan untuk meningkatkan keterampilan membaca siswa?

4. Apa faktor penghambat dan pendukung siswa dalam meningkatkan keterampilan membaca siswa?

\section{Hasil Wawancara dengan guru kelas 3}

Berdasarkan hasil wawancara dengan guru kelas 3 SDN Curug 1 pada pertanyaan pertama yaitu, sejauh mana kemampuan siswa dalam mengikuti pembelajaran keterampilan membaca?

"pada point pertama ini kemampuan siswa itu bervariatif anak mampu membaca, memahami isi bacaan yang di baca, selain itu siswa mampu mengembangkan isi bacaannya dengan karyanya sendiri secara tertulis maupun lisan seperti memberikan saran dan masukan, pendapat pada teks yang sudah dibacanya"

Pertanyaan kedua yaitu, bagaimana kondisi suasanya kelas ketika siswa mengikuti pembelajaran keterampilan membaca?

"konidisi kelasnya tenang, fokus, hening, seketika meskipun kadang juga kurang kondusif karena mereka mungkin merasa bosan"

Pertanyaan ketiga yaitu, Bagaimana pengembilan metode atau strategi dalam meningkatkan keterampilan membaca?

"metode yang digunakan untuk meningkatkan kemampuan membaca ialah dengan metode membaca cepat dan nyaring" 
Pertanyaan keempat yaitu, Apa faktor - fakto penghambat dan pendukung dalam meningkatkan keterampilan membaca?

"faktor penghambatnya minat kurangnya minat membaca ialah kurangnya ketersediaan buku dalam perpustakaan, siswa merasa jenuh atau bosan saat membaca, sedangkan untuk faktor pendukungnya, yaitu memfasilitasi perpustakaan dengan berbagai macam buku yang kreatif agar minat baca anak. meningkat, menggunakan metode yang kreatif dan inovatif”.

Tabel aspek yang diamati

\begin{tabular}{|l|l|l|}
\hline No & Aspek yang diamati & Respons siswa \\
\hline 1 & $\begin{array}{l}\text { Siswa dapat menyimpulkan hasil } \\
\text { bacaannya sendiri }\end{array}$ & Sangat baik \\
\hline 2 & $\begin{array}{l}\text { Kondisi kelas saat guru } \\
\text { menyuruh membaca }\end{array}$ & Baik \\
\hline 3 & $\begin{array}{l}\text { Siswa dapat membaca dengan } \\
\text { nyaring }\end{array}$ & Baik \\
\hline 4 & $\begin{array}{l}\text { Siswa dapat membaca dengan } \\
\text { cepat }\end{array}$ & Baik \\
\hline
\end{tabular}

Berdasarkan hasil wawancara dengan guru ditemukan beberapa faktor-faktor penghambat dan pendukung siswa untuk melakukan kegiatan keterampilan membaca di SDN Curug 1 faktor yang penghambat yang pertama (1) siswa terkadang merasa bosan saat melakukan kegiatan membaca dalam waktu yang lama masalah ini sepertinya yang menjadi masalah di setiap anak yang berada di indonesia dikarenakan mereka jika di suruh melakukan kegiatan membaca yang lama selalu merasa bosan. Permasalahan ini sebenarnya bisa di atasi dengan guru memberikan buku-buku yang menarik seperti buku yang memiliki gambar dan cerita yang di sukai oleh siswa sehingga mereka bisa membaca bukunya sampai tuntas dan tidak merasa bosan saat membacanya. Faktor penghambat kegiatan yang kedua ( 2 ) yaitu kurangnya bahan buku bacaan yang ada di perpustakaan sekolah,pihak sekolah seharusnya sudah menyediakan bahan bacaan dengan berbagai pilihan buku yang menarik sehingga 
siswa yang telah selesai membaca buku yang satu akan membaca buku yang satunya lagi hal itu dikarenakan banyak pilihan buku yang menarik di perpustakaan sehingga siswa minat untuk membacanya. perpustakaan juga harus memiliki ruangan yang nyaman, bersih dan rapi siswa akan lebih tertarik mengunjungi perpustakaan. Ada banyak perpustakaan di sekolah-sekolah saat ini yang ruangannya tidak nyaman atau bahkan sumpek dikarenakan penataan bukunya tidak rapi dan tidak sesuai dengan urutan jenis bahan bacaannya, jika perpustakaannya menurut siswa itu tidak nyaman dan rapi siswa tersebut bahkan tidak tertarik untuk mengunjunginya sedangkan jika perpustakaan itu rapi , bersih dan nyaman tidak bisa dipungkiri kalau siswa tersebut akan mengunjunginya.

Selanjutnya ada beberapa faktor pendukung siswa untuk minat baca di SDN Curug 1 yang pertama ( 1 ) guru SDN curug 1 sudah kreatif dan inovatif, guru yang kretaif dan inovatif ini mampu untuk menumbuhkan minat baca siswa contohnya yaitu guru membuat "moveable book" cara membuatnya juga sederhana, tidak harus mengeluarkan banyak biaya, cukup dengan memanfaatkan alat tulis kantor ( ATK) seperti kertas bufallo, selotip, double tape, gunting, lem, pensil serta gambar- gambar yang menarik untuk siswa. Caranya itu yang pertama, memotong kertas buffalo berbentuk persegi panjang, yang kemudian di lipat kedua sisinya. Setelah itu, gunting bagian tengah secara menyerong kertas yang berbentuk persegi panjang. Bagian yang di lipat diberi double tape, lalu tempelkan ke bagian dalam buku.lalu jadilah gambar yang muncul seolah-olah berdiri dan nampak seperti tiga dimensi ketika buku dibuka. Kegiatan yang seperti itulah yang akann menumbuhkan minat baca siswa karena bukunya menarik untuk dibaca tidak hanya itu siswa juga dapat ber kreatifitas dengan membuatnya sendiri sesuai yang di inginkan siswa tersebut.

Selanjutnya pada tabel aspek pengamatan yang pertama ( 1) siswa mampu menyimpulkkan hasil bacaannya sendiri menunjukan respon yang sangat baik hal ini menunjukan bahwa pembelajaran yang dilakukan oleh guru kelas 3 itu berhasil dikarenakan siswa jika disuruh membaca lalu siswa itu sudah bisa menyimpulkan hasil bacaannya sendiri tentu saja hal ini sangat baik untuk perkembanngan siswa tersebut. Pengamtan yang kedua ( 2 ) kondisi kelas saat guru menyuruh membaca, menunjukan respon siswa dalam kategori baik, saat peserta didik sedang membaca siswa-siswa 
tersebut terlihat begitu fokus terhadap bacaan dan juga suasananya tenang dan hening walaupun seketika tidak kondusif dikarenakan mereka bosan karena membaca terlalu lama. Pengamatan yang ketiga ( 3 ) siswa dapat membaca dengan nyaring menunjukan respon baik, hal ini dikarenakan saat guru menyuruh membaca secara nyaring siswa bisa melakukannya dengan walaupun ada beberapa siswa yang tidak melakukannya. Hasil pengamatan yang ketiga ( 3 ), siswa dapat membaca dengan cepat menunjukan respon yang baik, seperti hal nya membaca dengan nyaring, membaca dengan cepat juga siswa mampu melakukannya dengan baik, hanya sedikit siswa yang tidak mampu membaca dengan cepat.

\section{PEMBAHASAN}

Berdasarkan hasil penelitian yang dilakukan oleh peneliti dengan melalui wawancara guru kelas 3 SDN Curug 1 didapat beberapa faktor penghambatnya seperti siswa merasa bosan saat membaca sehingga suasan kelas tidak kondusif, dan kurangnya buku bacaan yang ada di perpustakaan.

Faktor penghambat inilah yang harus dihilangkan agar siswa mampu meningkatkan keterampilan membacanya siswa merasa bosan saat membaca mungkin ada salah pemilihan stratgei pembelajaran yang dilakukan oleh guru. Sedangkan faktor penghambatnya lainya seperti kurangnya bahan bacaan di perpustakaan itu sudah menjadi tugas sekolah agar siswanya tidak merasa jenuh saat membaca karena banyak pilihan buku bacaan.

Faktor pendukungnya ialah guru di SDN Curug 1 sudah kreatif, guru yang kreatif dapat membangun motivasi siswa dalam pembelajaran, guru yang kreatif saat ini dan yang akan mendatang sangat dibutuhkan untuk mendidik dan mengajar generasi emas yang penuh dengan tantangan. Guru kreatif adalah guru yang diharpkan mampu untuk mendiidk, mengajar, membimbing dan melatih siswa sehingga, lahirlah sebuah generasi yang kreatif dan inovatif serta juga berkarakter. Pada saat ini dilapangan kuantitas dan kualitas guru yang kreatif sangat terbatas atau bahkan kurang. Diharpkan kedepannya guru-guru yang kreatif bisa meningkat secara 
pesat atau sginifikan. Guru yang kreatif ialah guru yang selalu mencari metodemetode baru untuk mendapatkan pengetahuan baru.

Faktor pendukung lainnya adalah siswa di SDN Curug 1 di fasilitasi sebuah perpustakaan, perspustakaan di setiap sekolah sangat lah penting untuk siswa yang ingin membaca, bukan hanya persoalan ada atau tidaknya perpustakaan di sekolah tetapi juga ketersediaan bahan buku bacaan yang ada di perpustakaan, jika perpustakaan itu mempunyai ketersedia buku yang sedikit siswa akan kurang tertarik untuk mengunjunginya tetapi jika perpustakaan tersebut memiliki banyak ketersediaan stok bahan buku bacaan siswa akan tertarik untuk mengunjunginya. Perpustakaan sangat penting bagi siswa sekolah dasar untuk mencari dan menambah wawasan serta ilmu pengetahuan.

Guru di SDN Curug 1 menggunakan strategi atau metode membaca nyaring dan cepat, metode membaca ini siswa di fokuskan pada tekanan kata, kalimat, jeda dan menguasai tanda baca. Metode membaca nyaring adalah kegiatan yang paling penting dalam membangun pengetahuan dan keterampilan berbahasa peserta didik. Karena dalam membaca nyaring dan cepat merupakan suatu aktivitas kegiatan membaca yang menuntut aneka keterampilan

Startegi pembelajaran atau strategi instruksional sangat penting bagi pengajar atau guru untuk mencapai tujuan belajar yang akan di capai. Oleh karena itu guru harus bisa menyusun dan memilih startegi desain instruksional dengan tepat guru juga bisa menggunakan media-media pembelajaran yang tepat.

Dengan menggunakan stategi atau metode desain pembelajaran guru diharapkan bisa membangun motivasi peserta didik agar bisa lebih meningkatkan kemampuan membacanya. Dengan penggunaan metode Desain pembelajaran yang tepat bisa di pastikan siswa dapat meningkatkan minat bacanya sehingga keterampilan membaca siswa itu pun meningkat 


\section{KESIMPULAN}

Berdasarkan hasil penelitian yang telah dilakukan oleh peneliti dengan guru kelas 3 SDN Curug 1 di dapat kesimpulannya yaitu keterampilan siswa itu bervariatif ada yang cepat menangkap dan ada yang lambat dalam menangkap materi pembelajaran, pada saat pembelajaran berlangsung suasana kelas kondusif walaupun kadang jadi tidak kondusif dikarenakan siswa tersebut bosan, kebosanan siswa inilah yang menjadi tugas guru gimana cara menghilangkannya, peneliti menyarankan dengan menggunakan buku bacaan yang di sukai siswa dan gambar yang menarik.

Metode yang digunakan guru yaitu metode membaca cepat dan nyaring dan juga guru harus mempersiapkan penyusunan stratgei instruksional agar sesuai dengan capaian pembelajaran. Serta faktor penghambatnya yaitu kurangnya bahan bacaan yang ada dan faktor pendukungnya buku bacaan di perpustakaan dengan buku yang kreatif sehingga di sukai para siswa.

\section{DAFTAR PUSTAKA}

Dalman. (2017). Keterampilan membaca . Jakarta : Rajawali Pers.

Erma Yulia Saputri, Riris Setyo Sundari, \& Zainal Arifin. (2019). Analisis

Kemampuan Membaca Siswa Kelas II C Sekolah Dasar Negeri Gisikdrono 02 Semarang. Seminar Pendidikan Indonesia .

Ginting, C. (2013). Kiat Belajar di Perguruan Tinggi. Jakarta : Grasindo.

Iskandarwasid, s. D. (2011). Strategi pembelajaran bahasa. Bandung : Rosda .

J. Moleong, L. (2014). Metode Penelitian Kualitatif (Revisi ed.). Bandung: PT Remaja Rosdakarya.

Miftah. (2013). Fungsi dan peran Media Pembelajaran sebagai upaya peningkatan kemampuan belajar siswa . 95-105.

Moleong, L. (2007). Metodologi Penelitian Kualitatif. Bandung: Remaja Karya.

Nurhadi. (2010). Membaca Cepat dan Efektif. Bandung: Sinar Baru Algensindo Bandung.

Rahman , B., \& Haryanto . (2014). PENINGKATAN KETERAMPILAN MEMBACA PERMULAAN MELALUI MEDIA FLASHCARD PADA SISWA KELAS I SDN BAJAYAU TENGAH 2. Jurnal Prima Edukasia, 128.

Ratna, \& Wulan. (2010). Peranan Intelegensi, penguasaan kosa kata, sikap dan minat terhadap kemampuan membaca pada anak . Journal uny. 
sandu siyoto, \& ali sodik. (2015). DASAR METODOLOGI PENELITLAN. Sleman: Literasi Media Publishing.

Setiawan, A. A. (2018). Metodologi Penelitian Kualitatif. Jawa Barat: CV Jejak .

Setyosari, P. (2020). DESAIN PEMBELAJARAN. Jakarta Timur: PT Bumi Aksara.

Susanna Vonny Noviana Rante . (2014). MENINGKATKAN KETERAMPILAN MEMBACA PERMULAAN MELALUI METODE BERMAIN PADA SISWA KELAS I SD NEGERI 5 MAKALE KABUPATEN TANA TORAJA. Jurnal Keguruan dan Ilmu Pendidikan, 3. 